\title{
Cannabis to concussion
}

7 his issue of Neurology ${ }^{\circledR}$ Clinical Practice features thought-provoking articles on disparate topics. Gardner et al. (p. 285) tackle chronic traumatic en-

cephalopathy, describing clinical and pathologic features in 14 self-referred symptomatic former professional football players. Harold Adams (p. 296) details the controversy surrounding treatment of patients who awaken with stroke symptoms whose time of onset cannot be established. Borsook and Dodick (p. 317) make a passionate plea to recognize the disabling nature of migraine. While it is not clear whether challenges to the Affordable Care Act will result in large numbers of Americans returning to the rolls of the uninsured, Taylor et al. (p. 302) chronicle the creation of a free neurology clinic that might serve as a model for others.

There are also several fine articles focused on practice issues. Advanced practice providers (APPs, e.g., nurse practitioners and physician assistants) have become increasingly prominent in both general medical and surgical practices as well as specialty practices such as neurology. Schwarz et al. (p. 333) outline the creation of an American Academy of Neurology Work Group to address the effect of APPs in neurologic practices. Gerald Dal Pan (p. 338), a neurologist and long-time US Food and Drug Administration (FDA) administrator, demystifies the role and function of the FDA. Fife et al. (p. 344) offer an update and companion to the systematic review on medical marijuana in neurologic diseases published in 2014 in Neurology, focusing on payment policy issues. Finally, we have several intriguing cases to stimulate your differential diagnostic skills.

We hope you enjoy these articles as much as we do. Thanks for your support and perspectives.

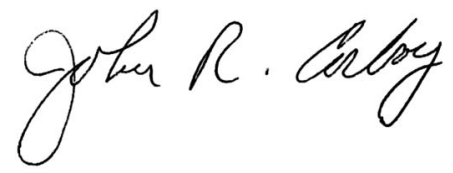

John R. Corboy, MD, FAAN

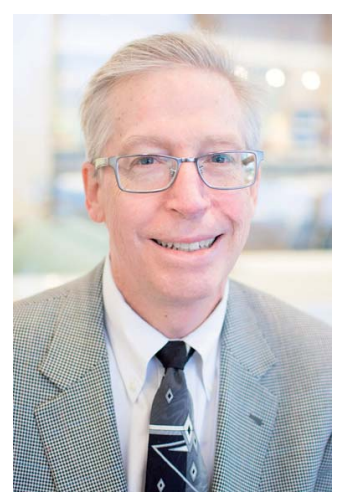




\section{Neurology ${ }^{\circ}$ Clinical Practice}

Cannabis to concussion

Neurol Clin Pract 2015;5;273

DOI 10.1212/CPJ.0000000000000167

This information is current as of August 17, 2015

Updated Information \&

Services

Permissions \& Licensing

Reprints including high resolution figures, can be found at:

http://cp.neurology.org/content/5/4/273.full.html

Information about reproducing this article in parts (figures,tables) or in its entirety can be found online at:

http://cp.neurology.org/misc/about.xhtml\#permissions

Information about ordering reprints can be found online:

http://cp.neurology.org/misc/addir.xhtml\#reprintsus

Neurol Clin Pract is an official journal of the American Academy of Neurology. Published continuously since 2011, it is now a bimonthly with 6 issues per year. Copyright (C) 2015 American Academy of Neurology. All rights reserved. Print ISSN: 2163-0402. Online ISSN: 2163-0933.

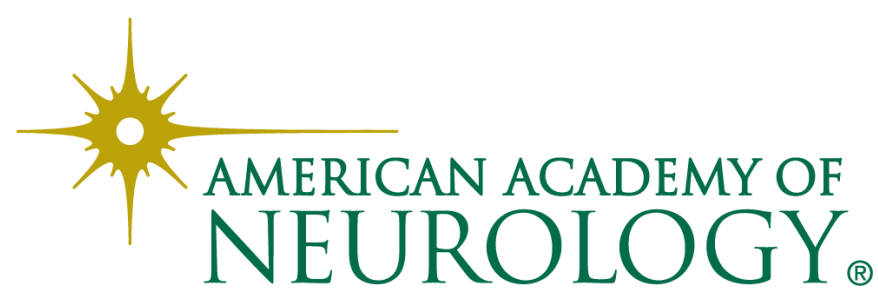

